\title{
sciendo
}

\section{From knowledge workers to knowmads: skills, roles and attributes - A literature review}

\author{
Andra Nicoleta ILIESCU \\ National University of Political Studies and Public Administration, Bucharest, Romania \\ andra.iliescu@facutateademanagement.ro
}

\begin{abstract}
This paper aims to achieve a comprehensive image of the knowmad worker. Over the past few decades, knowledge workers have been at the center of academic and practical interest in the knowledge management field. Without excluding other management directions, this specific segment developed for a better understanding and sustaining of organizational knowledge dynamics. Recently - associated with unpredictable changes in all aspects of our lives, that have a direct impact on the business market - the knowmad typology gained increasingly more interest in the academic field, being recognized as an emergent group of learners and workers. They are associated with better adapting skills, increased innovation and creativity performances compared to previous knowledge workers and these qualities ensure individual and organizational competitivity in the contemporary society, as this paper will show. While the primary focus of existing knowmad literature is on the education shift towards a competence-based approach, the working coordinates of these workers remain in a secondary position in the existing literature. Through extensive literature review, and by using a data analysis engine, key concepts have been identified and analyzed in a systematic comparison between knowmads and knowledge workers. The first part of this paper is focused on placing the knowmad workforce into the relevant social context. In the second part and third part, the knowledge worker and knowmad typologies are analyzed from skills, roles, and attributes perspective. Findings obtained through this research show that the knowmad workforce represents the unavoidable future worker, which is both a consequence and a solution for a business environment defined by continuous unpredictable changes. In this respect, future research directions should be focused on the management of knowmad workforce.
\end{abstract}

Keywords: knowledge economy, knowledge workers, knowmads, Society 3.0.

\section{Introduction}

The goal of this study is to contribute to the better understanding of a new type of knowledge actor of the mid- $21^{\text {st }}$ century. In recent decades, the interest in organizational knowledge as a resource and for knowledge workers as prime holders of this asset grew in both theoretical and practical management fields. Knowledge has been, from historical times, linked to development and progress (David \& Foray, 2002). Moreover, knowledge, its management, and its organizational dimension have always been constituent parts of the organizations, even though they did not have the importance they have in current days (Bratianu, 2015; Nonaka \& Takeuchi, 2019). Only recently, the interest surrounding these concepts started to develop (Hadad, 2017; Rhem, 2017; Tomé, 2020).

In the knowledge economy, knowledge assets become essential assets for organizations: knowledge-based economies rely on the generation, dissemination and utilization of both knowledge and information (OECD, 1996). When it comes to generating and delivering new products and services in the knowledge society, it's critical to use knowledge assets as a driver of both innovative ways of doing so while also understanding a market that's much more quality and value focused (Tomé, 2020). This shift brought the knowledge worker in the spotlight of organizational development as early as 1959, through the visionary work of Peter Drucker.

DOI: $10.2478 /$ picbe-2021-0013

(C) 2021 A. N. Iliescu, published by Sciendo.

This work is licensed under the Creative Commons Attribution 4.0 License. 
According to Davenport, amongst all actors of the knowledge economy, it is the knowledge workers that own the control over the production of outputs (Davenport, 2005), as they put their intellectual capital at work to help the organization reach defined objectives and strategies (Bratianu, 2015). Reinhardt, Schmidt, Sloep, and Drachsler go one step further and conclude, based on extensive literature review that knowledge workers can even be seen as work assets whose intelligent component is targeted by knowledge management system (Reinhardt et al., 2011). In the knowledge economy, firms develop new capabilities that resembles to those of learning organizations (Bratianu et al., 2020b; Garcia-Perez et al., 2020).

A new segment of knowledge worker literature is developing around a new type of learner and worker of the 21 ${ }^{\text {st }}$ century: the knowmad (Cobo \& Moravec, 2011; Kubik, 2013; Moravec, 2008, 2013a, 2013b; Garcia, 2012a, 2012b; Orel, 2020). The focus in the knowmad academic field is dedicated to the shifts in formal education and alternative competence development environments (e-learning). Even if authors like Garcia (2012a, 2012b) or Cobo (2011) discuss knowmad skills or roles in the organizations, this represented only a secondary interest of their research, being presented as a result of the aforementioned educational shifts. As such, we identified a need for a better, more comprehensive analysis of the knowmad workers in the literature. The present paper aims to provide this analysis from a roles, skills, and attributes perspective. Our research hypothesis is H: Knowmads are a new kind of knowledge workers. Consequently, we defined two research questions: RQ1: What defines the knowmads? and RQ2: What differentiates the knowmads from the knowledge workers?

\section{Methodology}

The methodology used for the qualitative research consists of identifying the relevant literature in the field available on accredited databases, by searching relevant keywords and descriptors closely related to the central topic of interest of this paper. Subsequently, only the proper scientific articles and research papers have been selected for the qualitative analysis, ensuring that a comprehensive view of the concept is provided by the sources. Finally, using a qualitative data analysis engine, selected literature has been coded and the main areas of interest were highlighted.

To identify relevant publications for this paper, online public libraries, the author's personal library, and accredited databases have been used, such as ProQuest Central, Science Direct, Wiley Online Library, Web of Science, Internet Books Archive and Research Gate. For each of them, similar search terms have been used to search and identify relevant publications. The investigation was restricted to English and Spanish-language materials that were readily accessible at the time of the study (January 2021).

Descriptive search terms have been selected in two different research phases: the first set of descriptors has been established based on the first research question and was intricately linked to the Knowmad taxonomy (Knowmads, Knowmad society, Knowmadic workforce). After the first research phase, part of the second phase sources has been identified using the snowball method or by analyzing the reference lists of the first phase research findings. Another part of the sources has been located after establishing a second set of descriptors, linked to the second research question. Therefore, the second set of descriptors included larger or related concepts that proved particularly important in positioning this papers' main topic into the correct context (such as Society 3.0, knowledge economy, knowledge management, knowledge worker). The rationale for selecting key sources for this paper was based on multiple criteria. Amongst them, we name the coherence with the subject of the present paper and with the research questions, the adherence to the condition that 
the source was primary source research, the high number of citations of the majority selected articles, both the historical and critical value of many sources.

To ensure a well-organized systematic literature review, the NVivo software has been used for the qualitative research, as follows: all relevant digital references were uploaded into the software. During analysis, key areas of interest have been coded into different codes, out of which three categories stood out: skills, roles, and attributes. These also gave the conceptual flow of the present paper.

\section{Literature review}

\section{The dawn of a new society}

The first quarter century seems to be - more than anything else - defined by progress, changes, and uncertainty in the context of globalization becoming more visible and impactful in practically all parts of our existance (Beck et al., 2013; Nadkarni \& Prügl, 2020). Primary effects can be noticed in the societal and educational domains (Moravec, 2013b; Moravec \& van den Hoff, 2015) and secondary effects can be noticed eventually in the work field (fHokanson \& Karlson, 2013; Kubik, 2013). Authors are using interchangeably multiple concepts to refer to this new reality, as summarized in Figure 1.

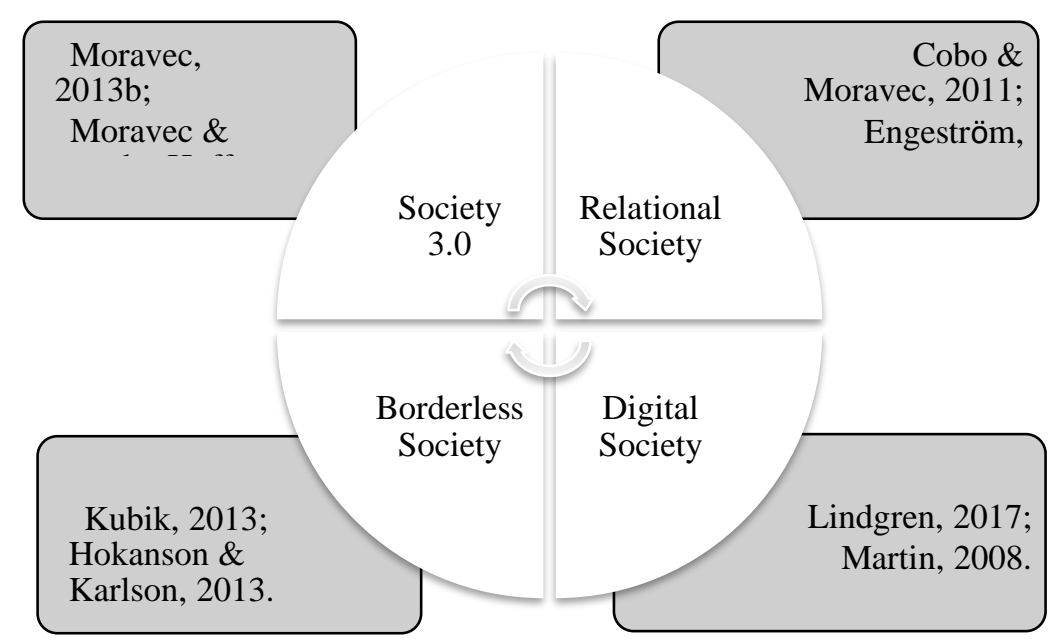

Figure 1. Society 3.0 concepts used interchangeably

Source: Author's own research.

The first concept is preferred in the literature relating to workforce dynamics in the global market: Society 3.0 or Knowmad Society is in Moravec's (2008, 2013a, 2013b) opinion an emerging society accessible for some individuals but is not as equally reaalistic to other individuals. The main engines of Society 3.0 are the increased pace of technological innovations and social changes as well as the steady globalization.

As summarized in Table 1, the author is focusing on understanding the key concepts that have been evolving through Industrial (Society 1.0) and Knowledge Society (Society 2.0) and their future development towards a Knowmad Society (Society 3.0).

Society 3.0 is a society defined by an enormous speed of change in the technological and social domains, that bear an exponential impact on education and business environment. It, therefore, becomes harder than ever to predict what might be next since subsequent changes occur 
unfold faster than ever. According to Thomas Davenport and Laurence Prusak, "knowledge is the most sought-after remedy to uncertainty" (Davenport \& Prusak, 2000, p. 25).

Table 1. Societies 1.0 to 3.0 across various domains

\begin{tabular}{|l|l|l|l|}
\hline \multicolumn{1}{|c|}{ Domain } & \multicolumn{1}{c|}{ Society 1.0 } & \multicolumn{1}{c|}{ Society 2.0 } & \multicolumn{1}{c|}{ Society 3.0 } \\
\hline Fundamental relationships & Simplicity & Complexity & Creative complexity \\
\hline Conceptualization of order & Hierarchy & Non-hierarchy & Autonomous/ intentional \\
\hline Relationship of parts & Mechanical & Re-constructed & Synergy \\
\hline Worldview & Controlled & Undefined & Delienate \\
\hline Causality & Single dimension & Reciprocal & Anti-causal \\
\hline Change Process & Assembling & Developing & Creative deconstruction/ collage \\
\hline Reality & Neutral & Subjective & Contextual \\
\hline Place & Local & Globalizing & Globalized \\
\hline
\end{tabular}

PICBE |

131

At organizational level, according to Igielski, the main challenge companies today is to register relevant achievements for the growing globalization (Igielski, 2017). Key conditions identified by the author in this respect are the integration of entrepreneurial employees within the organization and the achievement of high credibility on the market. In other words, they must invest a lot of attention inon partnerships, with both external and internal clientele (Igielski, 2017). By internal partnerships, the author emphasizes the attention that the new knowledge workers must receive from the managers, as they hold the right assets for the global knowledge economy. As Igielski highlights, qualified people are not a cost or resource; they are a capital essential for each organization (2017).

In the ever-changing, knowledge-based, technology-driven, and highly competitive business environment, talent competition becomes crucial for organizational high achievements (Florida, 2002). As present literature review study will show, the knowmad workers have the great potential of being the most suitable type of workers to participate to a business environment defined by volatility, uncertainty, complexity, and ambiguity (Bratianu et al. 2020a).

Even though the future is uncertain and unknown, we can sometimes look to the past to better understand the near future. Throughout this paper, I will present a comparison between knowledge workers and knwomads, from a skills, roles, and attributes perspective. A knowmad is a flexible knowledge worker, a person looking towards the future, a imaginative creator of new work setups, without boundaries of time or space (Moravec, 2008, 2013a, 2013b).

Based on this generally acknowledged definition in the field (Beck et al, 2013; Garcia, 2012a, 2012b; Orel, 2020) we have defined the research directions. A knowmad is a nomadic knowledge worker, an individual relying on his/ her creativity, imagination, and capacity to innovate, a flexible worker when it comes to time, location of work, people on his or her team or collaborators' teams, in addition to the tasks they are performing.

A knowmad is a person who travels from place to place in order to gain knowledge, both virtually and physically. According to Moravec, the originator of the concept, the knowmad concept is an extension of Peter Drucker's knowledge workers (Moravec, 2008). Additionally, in the knowledge management research field it is widely agreed (Davenport, 2005; Horwitz et al., 2003; Leon, 2015; Moravec, 2008, 2013a, 2013b; Schneckenberg, 2009), that the currently extended literature developed on the knowledge worker concept, has been growing on the shoulders of Peter Drucker's visionary work, dated back in the 1960s. Coined in 1959 and continuously refined until the end of his life, Drucker's knowledge worker concept enjoyed an increasingly 
growing interest in the academic literature and the managerial practice as of the 1990s (Leon, 2015, Tomé, 2020).

In his conceptual review paper, Surawski (2019) finds that the definition assigned by Davenport to the knowledge worker, stating that knowledge workers are individuals highly educated or specialized that are involved in knowledge activities, such as creation, sharing or implementation of knowledge (Davenport, 2005) is the most frequent one in the literature. The result is the tendency of authors to place knowledge workers in pharmaceutical, medical or biotechnological sciences (Salem \& Yousof, 2013), decision-making roles in organizations, supported by their high education, vast experience and their professional expertise (Davenport, 2005; Brinkley, 2006), in strategic or business development positions (Igielsky, 2017), or as information communication technology (ICT) specialist, able and willing to take accountability for their decisions (Zelles, 2015; Rosenthal-Sabroux \& Grundstein, 2008; Schneckenberg, 2009).

Moreover, Davenport (2015) develops an illustrative robot-portrait of the knowledge worker through a set of common attributes: they prefer autonomy in their workflows (1) that might often be difficult to break down into exact steps and handed over (2). This is explained by the nature of knowledge work itself, where the better practice of knowledge sharing could be shadowing or observation instead (3). In the knowledge economy, intellectual commitment is important, and it can be acquired through managerial trust (4) and openness to rely on the knowledge worker's expertise for correct decision making (5). Finally, knowledge workers are fearful to share their knowledge (6) because, in the globalizing work market, some of them paid the cost of becoming unemployed, after sharing their knowledge to less expensive teams.

With a similar approach as this paper follows, Surawski considers that a specific concept (i.e., knowledge worker) can be better understood through a comparison process with synonyms concepts. After identifying a series of fifteen synonyms proposed by peer authors or used in the practical organizational activity, the author finds that from all analyzed concepts, specialists are a valuable proxy since the concept is the closest one to the knowledge workers concept (Surawski, 2019). As an interesting common ground, the author finds that both specialists and knowledge workers have a deep, detailed knowledge on their filed of activity, benefit of higher education compared to other groups, they have sufficient experience that enables them with problem solving abilities, the skills of create and apply knowledge, they are both interested in life-long learning, having autonomy, while also being initiators but are not attracted to power (Surawski, 2019). The core difference between specialist and knowledge worker concepts is the fact that the first excludes manager roles (Surawski, 2019).

In summary, the most frequently mentioned skills of the knowledge workers in the literature are communication, problem solving, risk-taking, and learning skills, closely followed by flexibility, creativity, using of ICT and innovation skills (Leon, 2015). Finally, strategic skills, respect, sensitivity, empathy, political and economic literacy autonomy, and prioritization are identified by the author, based to extensive literature review.

A knowmad is an individual relying on his/ her creativity, imagination, and capacity to innovate. Knowmad is a term coined by Moravec in 2008 and further developed in the upcoming years (Cobo \& Moravec, 2011; Moravec, 2008, 2013a, 2013b; Moravec \& van den Hoff, 2015). In the concept originator's understanding, the knowmads are deterministically linked to the uncertain, technological, and globalized Society 3.0. We can therefore understand that the theoretical guidelines established by the originator around this concept are not fixed. This can be understood (a) due to still unfolding phenomena defining not-yet-completed contemporary trends and (b) due 
to the need for a continuous reflection on the topic that the author is explicitly encouraging in his book (Moravec, 2013b).

Focusing on the nature of work, Kubik (2013) finds through extensive literature review that knowledge work in contemporary hypercompetitive society tends to become less specialized in specific individual fields of activity and more social, imaginative, and improvisational work, as presented in Figure 2. Therefore, we find that intensive specialization and know-how are no longer quintessential requirements for knowmads, even though they remain important assets. What comes first, though, is the dynamism, improvisation, sharing, global adapting and networking.

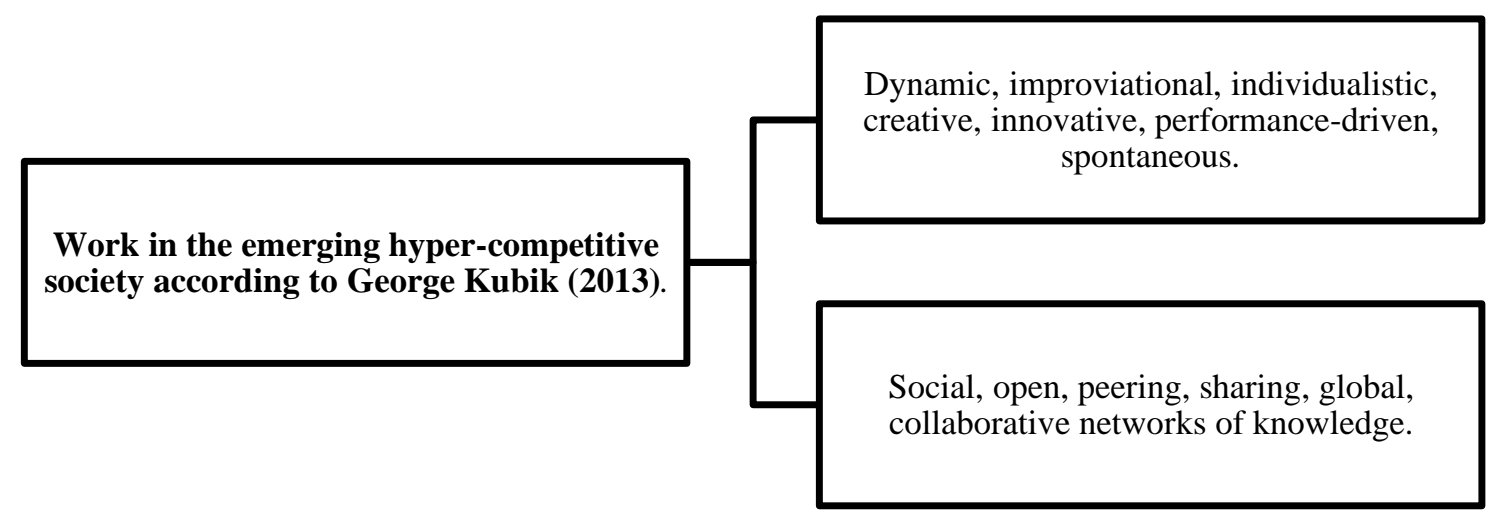

Figure 2. Work in the emerging hyper-competitive society according to Kubik (2013)

Source: Adapted from Kubik, 2013.

In the new society ICT assets are gaining increasingly more attention as tools accessed for continuous learning. While ICT using skills and learning skills were already knowledge workers' specific skills, they now facilitate instant access to a high variety of knowledge resources, becoming important learning tools. As such, an instrumental asset of Society 3.0 competitive and agile worker is his digital and technological sophistication reflected in the ability to manipulate ICT creatively (Moravec, 2008, 2013b; Cobo \& Moravec, 2011). According to Cobo (2013), there are five ICT competencies that enable the creation and re-reaction of knowledge, presented in Figure 3.

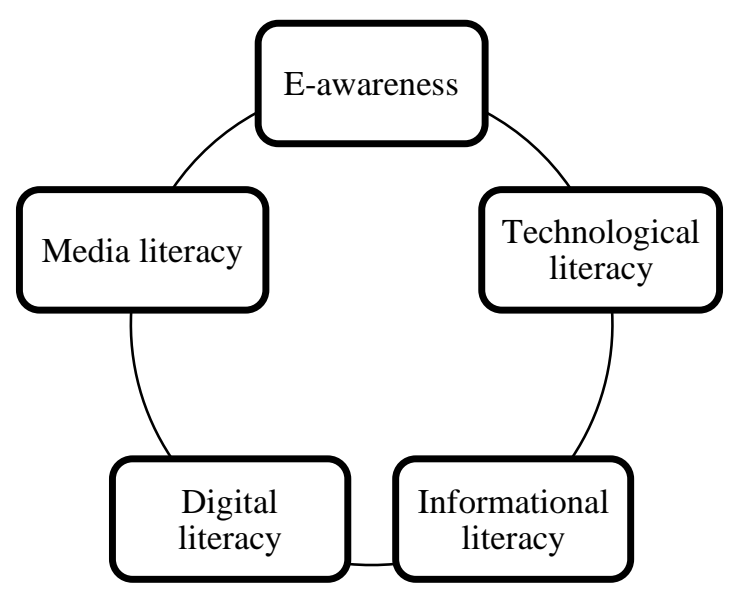

Figure 3. The five concepts of ICT competencies for Knowmads according to Cobo (2013)

Source: Adapted from Cobo, 2013.

DOI: 10.2478/picbe-2021-0013, pp. 128-138, ISSN 2558-9652 |

Proceedings of the $15^{\text {th }}$ International Conference on Business Excellence 2021 
From a skills perspective, the main challenge for knowmads is to ride the uncertainty wave of the new society. Referring to knowmad workforce, Cristóbal Cobo and John Moravec (2011) establish a first set of skills, grouped in three main categories, as presented in Figure 4. We note problem solving, flexibility, creativity, and innovation as some of the most important skills that the knowledge workers and the knowmads share.

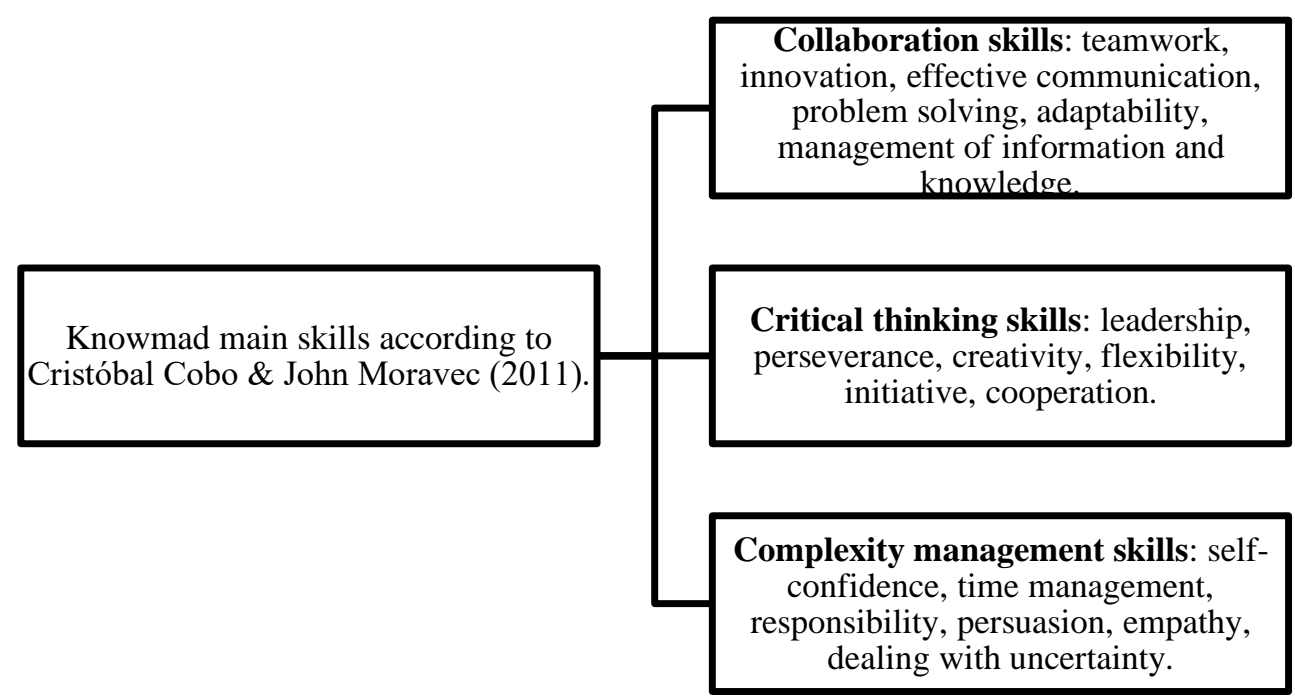

PICBE |

Figure 4. Main knowmad skills according to Cobo \& Moravec (2011)

Source: Adapted from Cobo \& Moravec, 2011.

While creativity and courage to take risks are two of the frequent knowledge workers skills, we find them also in the apanage of the knowmads. Nevertheless, it is important to note that Hokanson and Karlson (2013) are targeting exclusively these two key non-cognitive skills as key for the future of work and education, as presented in Figure 5.

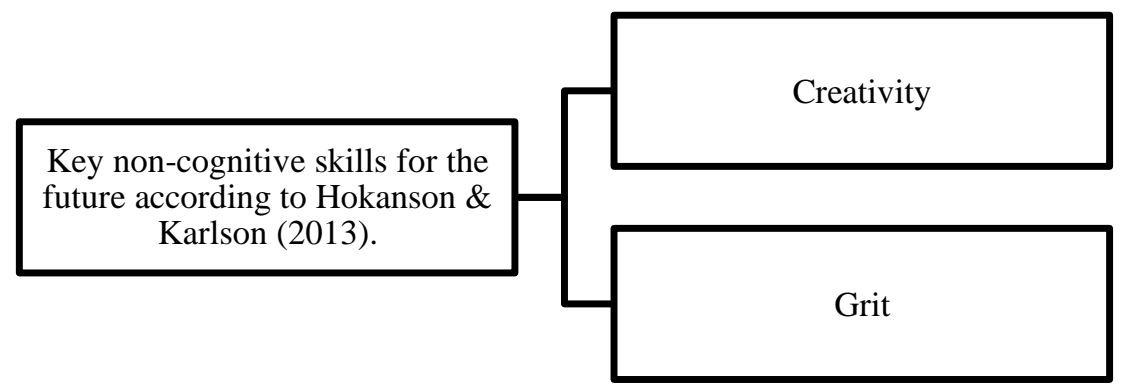

Figure 5. Key non-cognitive skills of the future according to Hokanson \& Karlson (2013)

Source: Adapted from Hokanson \& Karlson, 2013.

While most knowmad skills are not unique for this group of workers, it is important to understand the weight that is being put on contextual skills that are ensuring the competitivity of the latter on a volatile market, where innovative, creative, and imaginative human capital becomes knowledge good subject to global competition. According to Brad Hokanson and Roger M. Karlson, we're moving towards a borderless society, with "workers" and "work" moving across national lines and throughout the globe like produced commodities. (Hokanson \& Karlson, 2013). For example, while problem solving is a common skill between the two groups of workers, Cobo and Moravec add a complexity layer when they mention that knowmads possess competencies to 
solve unknown problems in different contexts (Cobo \& Moravec, 2011). Because of this, we see new abilities in the knowmads such as leadership, tenacity, self-confidence, and persuasion that aren't present in knowledge workers.

A similar tendency to zoom in on essential knowledge creation roles is also identified when analyzing the evolution of knowledge worker roles towards knowmad roles within organizations. Wolfgang Reinhardt, Benedikt Schimidt, Peter Sloep and Hedrick Drachsler (2011) developed a knowledge worker typology, based on two empirical studies. The typology has been further adapted by Blanca Garcia (2012a) into a knowmad typology of network actors, summarized in Table 2. While key knowledge creation roles have been transmitted from one workers generation to the other, knowledge worker roles not so powerfully linked to knowledge creation and innovation have been removed from the initial typology: the controller, the helper, and the organizer.

Table 2. Knowmad typology, profile, and key activities

\begin{tabular}{|l|l|l|}
\hline \multicolumn{1}{|c|}{ Knowmad activity } & \multicolumn{1}{|c|}{ Responsibilities } & \multicolumn{1}{|c|}{ Key activities } \\
\hline Collection & Classification, organization, indexation. & $\begin{array}{l}\text { Expert search, information } \\
\text { search, information } \\
\text { organization. }\end{array}$ \\
\hline Connection & $\begin{array}{l}\text { Relationship opportunists who bring disparate parties } \\
\text { together. }\end{array}$ & $\begin{array}{l}\text { Search for expert } \\
\text { information; monitoring; } \\
\text { networking; service search. } \\
\text { Analyses. Dissemination. }\end{array}$ \\
\hline Communication & $\begin{array}{l}\text { In order to meet audience needs, storytellers must } \\
\text { perform tasks such as information analysis and } \\
\text { presentation, as well as preparing and presenting reports } \\
\text { as well as meeting minutes and other meeting records. }\end{array}$ & $\begin{array}{l}\text { Authoring, co-authoring, } \\
\text { dissemination, networking. }\end{array}$ \\
\hline Creation & $\begin{array}{l}\text { Experimenting and developing ideas, models, and } \\
\text { systems that other people may use, as well as penning } \\
\text { academic papers and books. }\end{array}$ & $\begin{array}{l}\text { Information gathering, } \\
\text { analysis, and dissemination. }\end{array}$ \\
\hline Criticism & $\begin{array}{l}\text { Analyzing knowledge, looking for inconsistencies, } \\
\text { mistakes, dangers, and opportunities. }\end{array}$ & $\begin{array}{l}\text { Analysis, information } \\
\text { gathering, surveillance, and } \\
\text { networking are all part of } \\
\text { the process. }\end{array}$ \\
\hline Consumption & $\begin{array}{l}\text { The development of relationships based on mutual trust, } \\
\text { goodwill, and the ability to add value }\end{array}$ & $\begin{array}{l}\text { Data collection and analysis, } \\
\text { information dissemination, } \\
\text { information search, and } \\
\text { networking. }\end{array}$ \\
\hline
\end{tabular}

Source: Adapted from Garcia, 2012a.

A knowmad is a flexible worker when it comes team members or collaborators, time, and space as well as tasks he/she is performing. For knowmads, their natural habitat is a hybrid of virtual and physical worlds where they share ideas, build networks, and participate in sophisticated knowledge sharing mechanisms outside and throughout organizations, within and among different cultures, within or outside national boarders (Moravec, 2008, 2013a, 2013b). Knowmads, as Garcia points out, are the new wave of knowledge brokers in our increasingly interconnected world (2013b). When it comes to knowledge sharing, this is a significant improvement from the norm among knowledge workers. Knowledge workers are reluctant to share their expertise, but knowmads are natural knowledge networkers.

While working and living a virtual-physical hybrid life, nomadism remains the signature attribute of the knowmads. Multiple authors (Cook, 2020; Kakihara \& Sørensen, 2001; Orel, 2019, 2020; Müller, 2016, Nash et al.,2018, Wang et al., 2018) focus their attention on recent workforce 
migration trends. These are new ways for knowledge workers to fulfill their professional obligations, generally outside of the traditional working norms. A first group of authors focus on physical or geographical transience and are developing their studies starting from Makimoto and Manners' concept of digital nomads, established in 1996 (Cook, 2020; Kakihara \& Sørensen, 2001; Orel, 2020). To paraphrase Cook, the digital nomad concept of freedom is frequently a rather vague and easy to subjectify perception that tries to draw a philosophy of living that completely filters out the clash between professional and personal duties (Cook, 2020. According to Moravec, by implementing their skills to use new technologies successfully, knowmads often succeed in transcending spatial traditional limitations (2013). This tendency is also visible with regards to mobile workers (Nelson et al., 2017; Ojala \& Pyöriä, 2018). Nevertheless, as Ojala and Pyöriä note, despite the expectation that new technology enables knowledge workers to enjoy work free of restrictions, "knowledge workers predominantly work at their employers' premises" (2018, p. 402).

A more frequent practice that raises some of the biggest contemporary challenges for employers is the professional transience of new knowledge workers in their quest for personal fulfillment (Horwizt et al.,2003; Lee-Kelley et al., 2007; Nelson \& McCann, 2010). As Nelson and McCann explain, there is a risk of knowledge loss associated with this practice (2010).

\section{Conclusion}

This study's findings suggest that knwomads are the new wave of knowledge workers, born out of the rapidly changing technical and social environments, as well as a response to the very unpredictable economic climate these factors generate. Welcoming the new mediators of knowledge within organizations is instrumental for forward looking businesses, that want to ensure global market survival and competitiveness. To attract, retain and stimulate knowledge creation within our organizations - remain key challenges for knowledge management for the near future. In order to identify the best strategies to meet these goals with respect to the new knowledge workers, a better understating on the knowmad workforce must be attained, and this is the main contribution of this paper.

\section{References}

Beck, K., Ilieva, R., Pullman, A., \& Zhang, Z. (2013). New work, old power: inequities within the labor of internationalization, On the Horizon, 21(2), 84-95.

Bratianu, C. (2015). Organizational knowledge dynamics: managing knowledge creation, acquisition, sharing, and transformation, Hershey, PA: IGI Global.

Bratianu, C., Hadad, S., \& Bejinaru, R. (2020a). Paradigm shift in business education: a competence-based approach, Sustainability, 12(4), 1348. DOI: 10.3390/su12041348.

Bratianu, C., Prelipcean, G., \& Bejinaru, R. (2020b). Exploring the latent variables which support SMEs to become learning organizations, Management \& Marketing. Challenges for the Knowledge Society, 15(2), 154-171. DOI: 10.2478/mmcks-2020-0010.

Brinkley, I. (2006). Defining the knowledge economy. London: The Work Foundation.

Cobo, C. (2013). Skills and competencies for knowmadic workers. In Moravec, J.W. (Ed.), Knowmad Society, 57-88. Minneapolis: Education Futures.

Cobo, C., \& Moravec, J.W. (2011). Aprendizaje invisible. Hacia una ecología de la educación. Barcelona: Laboratori de Mitjans Interactius / Publicacions i Edicions de la Universitat de Barcelona. 
Cook, D. (2020). The freedom trap: digital nomads and the use of disciplining practices to manage work/leisure boundaries, Information Technology \& Tourism, 22, 355-390.

Davenport, T.H., \& Prusak, L. (2000). Working knowledge. How organizations manage what they know, Harvard Business School Press, Boston.

Davenport, T.H. (2005). Thinking for a living: how to get better performance and results from knowledge workers, Boston, Massachusetts: Harvard University Press.

David, P. A., \& Foray, D. (2002). An introduction to the economy of the knowledge society, International Social Science Journal, 54, 9-23.

Engeström, Y. (2004). New forms of learning in co-configuration work, Journal of Workplace Learning, 16, 11-21.

Florida, R. (2002). The rise of the creative class: and how it is transforming work, leisure, community and everyday life, New York: Basic Books.

Garcia, B.C. (2012a). MAKCi: a knowledge-based development metrics experience, International Journal of Knowledge-Based Development, 3(4), 367-387.

Garcia, B.C. (2012b). New e-learning environments: e-merging networks in the relational society. Retrieved from: https://www.researchgate.net/profile/Blanca_Garcia5/publication/22483 0017_New_e-Learning_Environments_e-Merging_Networks_in_the_Relational_Society/ links/00b49531629495ce78000000.pdf .

Garcia-Perez, A., Cegarra-Navarro, J.G., Bedford, D., Thomas, M., \& Wakabayashi, S. (2020). Critical capabilities and competencies for knowledge organizations, Binkley: Emerald Publishing.

Hadad, S. (2017). Knowledge economy: characteristics and dimensions, Management dynamics in the Knowledge Economy, 5(2), 203-225.

Hokanson, B., \& Karlson, W.R. (2013). Borderlands: developing character strengths for a knowmadic world, On the Horizon, 21(2), 107-113.

Horwitz, F.M., Heng, C.T., Quazi, H.A. (2003). Finders, keepers? Attracting, motivating and retaining knowledge workers, Human Resource Management Journal, 13 (4), 23-44.

Igielski, M. (2017). Assumptions to the model of managing knowledge workers in modern organizations, Management, 21, 133-147.

Kakihara, M., \& Sørensen, C. (2001). Expanding the 'mobility' concept, ACM SIGGROUP Bulletin, 22 (3), 33-37.

Kubik G. H. (2013). Limitless: becoming remarkable in the borderless economy, On the Horizon, 21(2), 114-126.

Lee-Kelley, L., Blackman, D. A., \& Hurst, J. P. (2007). An exploration of the relationship between learning organizations and the retention of knowledge workers, The Learning Organization, 14(3), 204-221.

Leon, R.D. (2015). The future knowledge worker: an intercultural perspective, Management Dynamics in the Knowledge Economy, 3(4), 675-691.

Lindgren, S. (2017). Digital media and society. London: Sage.

Martin, A. (2008.) Digital literacy and the 'digital society'. In C. Lankshear and M. Knobel (eds) Digital Literacies: Concepts, Policies and Practices, 151-76, New York: Peter Lang.

Moravec, J.W. (2008). A new paradigm of knowledge production in higher education, On the Horizon, 16(3), 123-136.

Moravec, J.W. (2013a). Knowmad society: the 'new' work and education, On the Horizon, 21(2), 79-83.

Moravec, J.W. (Ed.) (2013b). Knowmad society, Minneapolis: Education Futures. 
Moravec, J.W., \& van den Hoff, R. (2015). Higher education 3.0: knowmads create their own value! in A. Daily-Hebert \& K.S. Dennis (Eds.). Transformative perspectives and processes in higher education, advances in business education and training, 233-240. Switzerland: Springer.

Müller, A. (2016). The digital nomad: buzzword or research category?, Transnational Social Review, 6(3), 344-348.

Nadkarni, S., \& Prügl, R, (2020). Digital transformation: a review, synthesis, and opportunities for future research, Management Review Quarterly, 70, 1-109.

Nash, C., Jarrahi, M.H., Shutherland, W., \& Phillips, G. (2018). Digital nomads beyond the buzzword: Defining digital nomadic work and use of digital technologies, In Transforming Digital Worlds, 207-2017, Springer International Publishing.

Nelson, S.B., Jarrahi, M.H., Thomson, L. (2017). Mobility of knowledge work and affordances of digital technologies, International Journal of Information Management, 37(2), 56-62.

Nelson, K., \& McCann, J.E. (2010). Designing for knowledge worker retention \& organization performance, Journal of Management and Marketing Research, 1, 1-18.

Nonaka, I., \& Takeuchi, H. (2019). The wise company: how companies create continuous innovation. Oxford: Oxford University Press.

OECD (1996). The knowledge-based economy. Retrieved from: https://www.oecd.org/officialdo cuments/publicdisplaydocumentpdf/?cote $=\mathrm{OCDE} / \mathrm{GD} \% 2896 \% 29102 \&$ docLanguage $=$ En .

Ojala, S., \& Pyöriä, P. (2018). Mobile knowledge workers and traditional mobile workers: assessing the prevalence of multi-locational work in Europe, Acta Sociologica, 61(4), 402-418.

Orel, M. (2019). Coworking environments and digital nomadism: Balancing work and leisure whilst on the move, World Leisure Journal, 61(3), 215-227.

Orel, M. (2020). Life is better in flip flops. Digital nomads and their transformational travels to Thailand, International Journal of Culture, Tourism and Hospitality Research.

Reinhardt, W., Schmidt, B., Sloep, P., \& Drachsler, H. (2011). Knowledge worker roles and actions - results of two empirical studies, Process Management (18), 150-174.

Rhem, A.J. (2017). Knowledge management in practice. Boca Raton, FL: CRC Press.

Rosenthal-Sabroux, G., \& Grundstein, M. (2008). A knowledge management approach of ICT, VNU Journal of Science, 24, 162-169.

Salem, N.B.B.S., \& Yusof, N.A.M. (2013). Diagnosing organization systems model for knowledge workers development in Malaysian biotechnology industry, Procedia - Social and Behavioral Science, 81(1), 618-623.

Schneckenberg, D. (2009). Web 2.0 and the empowerment of the knowledge worker, Journal of Knowledge Management, 13(6), 509-520.

Surawski, B. (2019). Who is a "knowledge worker" - clarifying the meaning of the term through comparison with synonymous and associated terms, Management, 23(1), 105-133.

Tomé, E. (2020). Actors in the knowledge economy: a typology, Management Dynamics in the Knowledge Economy, 8(4), 451-461.

Wang, B., Schlagwein, D., Cecez-Kecmanovic, D., \& Cahalane, M.C. (2018). Digital work and high-tech wanderers: three theoretical framings and a research agenda for digital nomadism, Australasian Conference on Information Systems.

Zelles, R. (2015). Better profitability through higher employee engagement in the knowledge worker age, Journal of HRM, 5(11), 62-72. 